\title{
Pemetaan Area Berisiko Persampahan di Kota Cimahi Berdasarkan Pedoman Strategi Sanitasi Kabupaten/ Kota 2018
}

\author{
Indah Fionita dan Iwan Juwana \\ Jurusan Teknik Lingkungan, Fakultas Teknik Sipil dan Perencanaan, ITENAS, Bandung \\ E-mail: juwana@itenas.ac.id
}

\begin{abstract}
ABSTRAK
Kota Cimahi merupakan salah satu kota di Jawa Barat yang masih menghadapi permasalahan persampahan, seperti terbatasnya penerapan kegiatan pemilahan sampah, terbatasnya jumlah Tempat Penampungan Sementara (TPS), terjadi pembuangan sampah secara sembarangan ke sungai, terdapat penanganan sampah dengan cara dibakar dan ditimbun, dan lain-lain. Dalam menindaklanjuti berbagai permasalahan sampah tersebut serta mencapai target $30 \%$ pengurangan sampah yang ditentukan oleh Kebijakan Strategis Nasional (Jakstranas), maka diperlukan suatu instrumen yang mampu menganalisis area berisiko berdasarkan tingkat risiko persampahan per kelurahan di Kota Cimahi. Area berisiko tersebut digambarkan dalam bentuk peta dengan mengacu pada pedoman Strategi Sanitasi Kabupanen/Kota (SSK) 2018. Area berisiko dinilai melalui skor 1 s.d. 4 secara berturut-turut untuk risiko sangat rendah, rendah, tinggi, dan sangat tinggi. Skor tersebut diperoleh dengan mengalikan parameter Impact dan parameter Exposure. Hasil penelitian ini menunjukkan terdapat tiga kelurahan dengan risiko persampahan sangat tinggi, yaitu Kelurahan Cibeureum, Setiamanah, dan Padasuka serta satu kelurahan dengan risiko persampahan tinggi, yaitu Kelurahan Melong. Penambahan jumlah unit pengolahan direkomendasikan di beberapa kelurahan sehingga terjadi perubahan skor area berisiko.
\end{abstract}

Kata Kunci: Kota Cimahi, Peta Area Berisiko, Persampahan

\begin{abstract}
Cimahi City is one of the cities in West Java that still faces solid waste problems, such as the limited implementation of waste sorting activities, the limited number of temporary shelter sites, the indiscriminate waste disposal on river, open burning of solid waste, etc. In following up on these various waste problems and achieving the target of $30 \%$ waste reduction determined by the National Strategic Policy, an instrument is needed to analyze risk areas based on the level of risk of solid waste per village in Cimahi City. These risk areas are depicted in the form of maps by referring to the 2018 District/City Sanitation Strategy Guidelines. Risk areas are assessed through a score of 1 s.d. 4 for very low, low, high and very high risks. The score is obtained by multiplying the Impact parameters and Exposure parameters. The results of this study indicate that there are three villages with very high risk of solid waste, namely Kelurahan Cibeureum, Setiamanah, and Padasuka and one village with high risk of solid waste, namely Kelurahan Melong. The addition of the number of processing units was recommended in several villages so that changes in the score of risk areas occurred.
\end{abstract}

Keyword: Cimahi City, Map of Risk Areas, Waste Solid

Jurnal Rekayasa Hijau - 79 


\section{PENDAHULUAN}

Pada tahun 2018, masih terdapat masyarakat Kota Cimahi yang membuang sampah secara sembarangan ke badan sungai. Salah satu sungai yang menjadi tempat pembuangan sampah tersebut adalah Sungai Curug yang berada di Kelurahan Utama, Kecamatan Cimahi Selatan, Kota Cimahi. Jenis sampah yang terdapat pada sungai tersebut adalah sampah rumah tangga seperti plastik bekas, sisa makanan dan minuman, styrofoam, dan lain-lain. Sebanyak 1,5 ton sampah yang berasal dari bagian utara dan tengah Kota Cimahi terbawa aliran air hujan sehingga bertumpuk di bagian selatan kota [1]. Keterbatasan jumlah Tempat Penampungan Sementara (TPS) sebagai fasilitas pemindahan sampah merupakan salah satu faktor yang menyebabkan terjadinya pembuangan sampah ke sungai. Sulitnya memperoleh izin dari masyarakat dan terbatasnya lahan menyebabkan minimnya jumlah TPS di Kota Cimahi. Selain terbatasnya fasilitas pemindahan sampah, terdapat beberapa permasalahan persampahan dari segi operasional teknis lainnya, seperti tidak memadainya kapasitas wadah sampah di beberapa lokasi sumber, terbatasnya penerapan kegiatan pemilahan sampah, terbatasnya jumlah armada pengumpul, terdapat penanganan sampah dengan cara dibakar dan ditimbun dalam tanah, dan lain-lain [2].

Mengacu pada Perpres No. 97 Tahun 2017, arah dan kebijakan pengelolaan persampahan terdiri atas pengurangan dan penanganan. Kebijakan strategis nasional (Jakstranas) menargetkan pengurangan sampah sebesar 30\% dan penanganan sampah sebesar 70\% dari angka timbulan sampah sebelum adanya Jakstranas di tahun 2025 [3]. Dalam menindaklanjuti berbagai permasalahan sampah yang terjadi di Kota Cimahi serta mencapai target yang ditentukan oleh Jakstranas, maka diperlukan suatu instrumen yang mampu menganalisis area berisiko berdasarkan tingkat risiko persampahan per kelurahan di Kota Cimahi. Instrumen yang dimaksud merupakan instrumen Strategi Sanitasi Kabupaten/Kota (SSK) yang selanjutnya dapat digunakan dalam perencanaan strategi pengelolaan persampahan di Kota Cimahi.

Tujuan dari pelaksanaan penelitian ini adalah (1) Menghitung skor area berisiko persampahan di Kota Cimahi; (2) Melakukan pemetaan area berisiko persampahan di seluruh kelurahan di Kota Cimahi; dan (3) Menyusun suatu strategi pengurangan persampahan berdasarkan area berisiko persampahan di Kota Cimahi.

\section{METODOLOGI}

Penelitian ini dilakukan mengikuti metodologi yang diuraikan pada Gambar 1.

\subsection{Penentuan Bobot Skor Impact dan Skor Exposure}

Penentuan bobot skor untuk parameter-parameter Impact dan Exposure dilakukan melalui metode Analitycal Hierarchy Process (AHP) [4]. Berikut ini merupakan tahapan yang dilalui dalam menggunakan metode AHP:

1. Mendeskripsikan masalah dan menetapkan solusi, lalu menyusun hierarki dari permasalahan tersebut.

2. Menetapkan prioritas elemen dengan membandingkan elemen secara berpasangan sesuai kriteria yang diberikan. Perbandingan dapat dilakukan dengan memberikan sebuah standa nilai antardua objek, misalnya nilai pertama sangat diutamakan, lebih diutamakan, diutamakan, cukup diutamakan, atau setara dibandingkan nilai kedua [20].

3. Menggabungkan pertimbangan terhadap perbandingan berpasangan agar mendapatkan seluruh prioritas. Langkah yang dilakukan pada tahapan ini adalah sebagai berikut: 
a. Menjumlahkan nilai-nilai dari setiap kolom pada matriks.

b. Membagi setiap nilai dari kolom dengan total kolom yang bersangkutan untuk mendapatkan normalisasi matriks.

c. Menjumahkan nilai-nilai dari setiap baris dan membaginya dengan banyak elemen sehingga diperoleh nilai rata-rata.

4. Menghitung konsistensi dalam pengambilan keputusan. Lagkah yang dilakukan pada tahapan ini adalah sebagai berikut:

a. Mengkalikan nilai dari setiap kolom pertama dengan prioritas relatif elemen pertama, nilai dari setiap kolom kedua dengan prioritas relatif elemen kedua, dan seterusnya.

b. Menjumlahkan nilai-nilai dari setiap baris dan membaginya dengan elemen prioritas relatif yang bersangkutan.

c. Menjumlahkan hasil bagi dengan banyak elemen yang ada. Nilai tersebut disebut sebagai $\lambda_{\text {maks }}$.

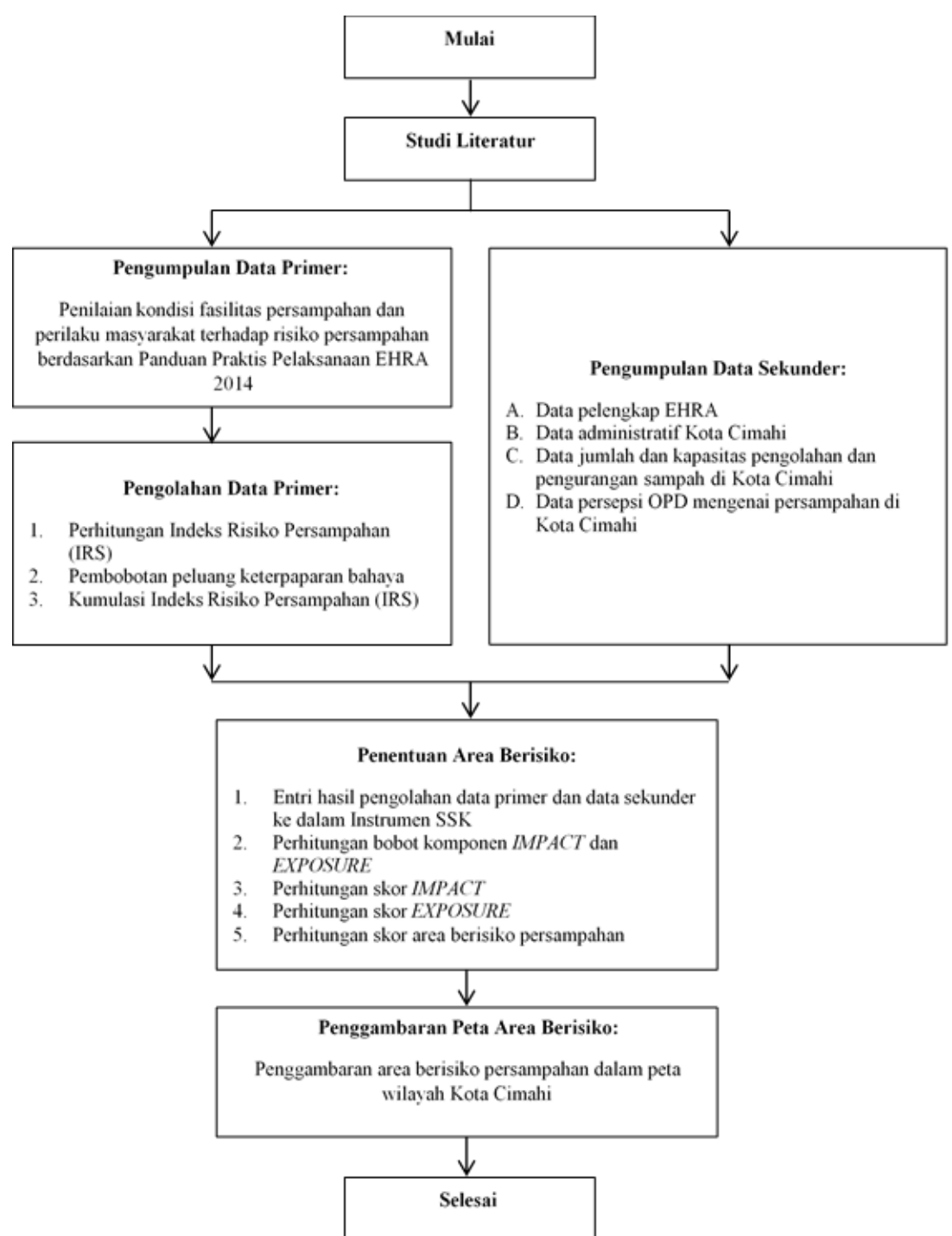

Gambar 1. Metodologi Penelitian 
5. Menghitung Consistency Index (CI) dengan persamaan berikut:

$\mathrm{CI}=\frac{\lambda_{\mathrm{maks}}-\mathrm{n}}{\mathrm{n}}$

Di mana:

CI = consistency index

$\mathrm{n} \quad=$ banyak elemen

6. Menghitung Consistency Ratio (CR) dengan persamaan berikut:

$\mathrm{CR}=\frac{\mathrm{CI}}{\mathrm{RCI}}$

Di mana:

$\mathrm{CI}=$ consistency index

$\mathrm{RCI}=$ random consistency index

7. Memeriksa konsistensi hierarki.

Jika nilainya lebih dari $10 \%$, maka penilaian data judgement harus diperbaiki. Namun, jika nilai $\mathrm{CR} \leq 0,1$, maka hasil perhitungan dinyatakan benar [5].

Nilai random index ditunjukkan pada Tabel 1.

Tabel 1. Nilai Random Index [4]

\begin{tabular}{ccccccccccc}
$\mathrm{N}$ & 1 & 2 & 3 & 4 & 5 & 6 & 7 & 8 & 9 & 10 \\
\hline $\mathrm{RI}$ & 0 & 0 & 0,58 & 0,90 & 1,12 & 1,24 & 1,32 & 1,41 & 1,45 & 1,49 \\
\hline
\end{tabular}

\subsection{Penentuan Skor Impact}

Impact atau dampak adalah pengaruh kuat yang mendatangkan akibat, baik negatif maupun positif [18]. Parameter Impact terdiri atas jumlah penduduk, kepadatan penduduk, angka kemiskinan, dan fungsi urban/rural. Setelah diperoleh pembobotan melalui Metode AHP, dilakukan perhitungan untuk masingmasing parameter. Berikut ini merupakan langkah perhitungan untuk parameter penentuan skor Impact [6]:

Jumlah Penduduk $=\frac{\text { Jumlah Penduduk Kelurahan }}{\text { Jumlah Penduduk Kota }} \times 100 \%$

Kepadatan Penduduk $=\frac{\text { Jumlah Penduduk } \text { (orang) }}{\text { Luas Area Terbangun (ha) }}$

Angka kemiskinan $=\frac{\text { Jumlah KK Miskin }}{\text { Jumlah KK per Kelurahan }} \times 100 \%$

Klasifikasi wilayah $=$ Skor 1 untuk daerah perkotaan dan skor 2 untuk daerah pedesaan

Langkah yang dilakukan sesudah memperoleh keempat nilai masing-masing parameter adalah melakukan normasilasi skor dengan persamaan berikut [6]:

$X>\left[X_{\min }+75 \% \cdot\left(X_{\max }-X_{\text {min }}\right)\right] \rightarrow$ Skor 4

$X>\left[X_{\min }+50 \% \cdot\left(X_{\max }-X_{\text {min }}\right)\right] \rightarrow$ Skor 3

$X>\left[X_{\min }+25 \% \cdot\left(X_{\max }-X_{\text {min }}\right)\right] \rightarrow$ Skor 2

$\mathrm{X}>\left[\mathrm{X}_{\min }+0 \% \cdot\left(\mathrm{X}_{\max }-\mathrm{X}_{\min }\right)\right] \rightarrow$ Skor 1

Di mana:

$\mathrm{X}=$ nilai suatu parameter

$\mathrm{X}_{\min } \quad=$ nilai terkecil parameter dari seluruh kelurahan di Kota Cimahi

$\mathrm{X}_{\max } \quad=$ nilai terbesar parameter dari seluruh kelurahan di Kota Cimahi

Setelah memperoleh skor keempat parameter dari hasil normalisasi, dilakukan perhitungan skor Impact dengan persamaan berikut [6]: 
Total Skor IMPACT $=\sum$ Skor tiap Parameter $\times$ Bobot

Total Skor IMPACT $=(\mathrm{JP} \times \% \mathrm{JP})+(\mathrm{KP} \times \% \mathrm{KP})+(\mathrm{AK} \times \% \mathrm{AK})+(\mathrm{UR} \times \% \mathrm{UR})$

Di mana:

$\mathrm{JP} \quad=$ Skor jumlah penduduk

$\% \mathrm{JP}=$ Bobot jumlah penduduk

$\mathrm{KP}=$ Skor kepadatan penduduk

$\% \mathrm{KP}=$ Bobot kepadatan penduduk

$\mathrm{AK}=$ Skor angka kemiskinan

$\% \mathrm{AK}=$ Bobot angka kemiskinan

$\mathrm{UR}=$ Skor urban/rural

$\%$ UR = Bobot fungsi urban/rural

Setelah diperoleh total skor Impact, dilakukan normalisasi skor Impact. Normalisasi skor Impact dihitung dengan Persamaan 6 s.d. 9.

\subsection{Penentuan Skor Exposure}

Exposure atau paparan adalah keadaan mengalami/merasakan sesuatu atau berada di bawah pengaruh sesuatu dalam situasi/tempat tertentu [19]. Parameter Exposure terdiri atas data sekunder, Indeks Risiko Sanitasi (IRS), dan persepsi Organisasi Perangkat Daerah (OPD). Setelah diperoleh pembobotan melalui Metode AHP, lakukan perhitungan untuk masing-masing parameter serta tentukan skornya. Berikut ini merupakan langkah perhitungan untuk parameter penentuan skor Exposure:

\section{Data Sekunder}

Nilai data sekunder yang dimaksud adalah persentase pengurangan persampahan di suatu kabupaten/kota. Persamaan yang digunakan untuk menghitung persentase pengurangan persampahan adalah sebagai berikut:

$\%$ Reduksi $=\frac{\sum(\text { Jumlah unit pengolahan } \times \text { Kapasitas pengolahan })}{\text { Jumlah timbulan sampah per kelurahan }} \times 100 \%$

\section{Indeks Risiko Sanitasi (IRS)}

Indeks risiko persampahan (IRS) diperoleh dari hasil pengolahan data primer komponen persampahan berdasarkan Panduan Environmental Health Risk Assessment (EHRA) 2014 [7]. Pengolahan data primer tersebut dilakukan melalui tahapan berikut[8]:

a. Tahapan pertama dalam mendapatkan nilai IRS adalah melalui perhitungan IRKL dengan cara membagi sumber bahaya, peluang keterpaparan bahaya, serta komponen di dalamnya dalam bentuk persentase untuk setiap wilayah kajian tertentu. Persamaan yang digunakan untuk menetapkan IRKL adalah sebagai berikut:

IRKL $=\frac{\text { Sumber Bahaya }}{\sum \text { Jumlah Penduduk per Kajian Wilayah }}$.

b. Tahapan kedua yang dilakukan adalah dengan memberikan bobot pada masing-masing komponen sumber bahaya dan peluang keterpaparan bahaya. Bobot $100 \%$ tersebut kemudian dibagi sesuai dengan banyaknya komponen yang ada dalam variabel bahaya dan peluang keterpaparan bahaya.

c. Tahap ketiga dalam memperoleh nilai IRS adalah menentukan kumulatif IRKL dengan cara menjumlahkan indeks risiko kesehatan yang telah dihitung dari hasil pembobotan pada tahap kedua. Hasil penjumlahan indeks risiko tersebut selanjutnya disebut sebagai IRS. 


\section{Persepsi Organisasi Perangkat Daerah (OPD)}

Persepsi OPD adalah penilaian risiko yang dibuat berdasarkan pengalaman atau keahlian anggota Pokja terhadap komponen persampahan di suatu kabupaten/kota. Dalam hal ini, jumlah OPD yang dilibatkan minimal 5 (lima) dan maksimal 9 (Sembilan) OPD. Nilai skor untuk persepsi OPD diperoleh dari suatu nilai yang paling sering dipilih oleh seluruh OPD yang dilibatkan [6].

Setelah memperoleh skor keempat parameter dari hasil normalisasi, dilakukan perhitungan skor Exposure dengan persamaan berikut:

Total Skor EXPOSURE $=\sum$ Skor tiap Parameter $\times$ Bobot

Total Skor EXPOSURE $=(\mathrm{DS} \times \% \mathrm{DS})+(\mathrm{IRS} \times \% \mathrm{IRS})+(\mathrm{OPD} \times \% \mathrm{OPD})$

Di mana:

DS $\quad=$ Skor data sekunder

$\%$ DS $=$ Bobot data sekunder

IRS $=$ Skor Indeks Risiko Sanitasi (IRS)

$\%$ IRS $=$ Bobot IRS

OPD = Skor Organisasi Perangkat Daerah (OPD)

$\% \mathrm{OPD}=$ Bobot OPD

Setelah diperoleh total skor Exposure, dilakukan normalisasi skor Exposure. Normalisasi skor Exposure dihitung dengan Persamaan 6 s.d. 9.

\subsection{Penggambaran Skor Area Berisiko Persampahan}

Skor area berisiko untuk masing-masing kelurahan dihitung menggunakan persamaan berikut:

Area Berisiko $=$ IMPACT $\times$ EXPOSURE

Di mana:

Area Berisiko $=$ skor area berisiko persampahan per kelurahan

IMPACT = skor Impact persampahan per kelurahan

EXPOSURE $\quad=$ skor Exposure persampahan per kelurahan

Hasil penentuan skor area berisiko ditampilkan dalam bentuk peta wilayah kajian dilengkapi dengan menggunakan warna yang dihasilkan dari perhitungan sebagai berikut[6]

- Warna dengan skor 4 = warna merah

- Warna dengan skor 3 = warna kuning

- Warna dengan skor 2 = warna hijau

- Warna dengan skor 1 = warna biru

Penggambaran peta dilengkapi dengan legenda yang menjelaskan arti warna dan tingkat risiko.

\subsection{Strategi Pengurangan Persampahan berdasarkan Area Berisiko Persampahan}

Peta area berisiko merupakan salah satu aspek yang dapat dijadikan dasar pertimbangan untuk penyusunan strategi persampahan [6]. Sasaran yang dicapai di dalam strategi ini adalah mengubah risiko persampahan yang tinggi dan sangat tinggi menjadi risiko rendah dan sangat rendah.

Beberapa hal yang mendasari strategi ini adalah sebagai berikut:

1. Skor Exposure dan skor Data Sekunder setiap kelurahan di Kota Cimahi memiliki pengaruh dalam mengubah skor akhir Area Berisiko Persampahan.

2. Skor Exposure dan skor Data Sekunder untuk setiap kelurahan ditargetkan bernilai maksimum 3 (risiko tinggi). 
3. Persentase pengurangan sampah memengaruhi skor Data Sekunder.

4. Target persentase pengurangan sampah di setiap kelurahan adalah lebih dari $11 \%$ (dalam rentang persentase pengurangan sampah untuk skor 3 pada Data Sekunder) dan lebih dari $21 \%$ (dalam rentang persentase pengurangan sampah untuk skor 2 pada Data Sekunder) sehingga dilakukan penambahan jumlah unit pengolahan untuk minimasi sampah di kelurahan terkait.

\section{HASIL DAN PEMBAHASAN}

\subsection{Penentuan Bobot Skor Impact dan Exposure}

Tahap pertama dalam menentukan pembobotan adalah melakukan penilaian perbandingan berpasangan untuk masing-masing parameter Impact dan Exposure.

Penilaian perbandingan berpasangan untuk elemen Impact yaitu:

- Kepadatan penduduk cukup diutamakan daripada jumlah penduduk.

- Angka kemiskinan diutamakan daripada jumlah penduduk.

- Jumlah penduduk cukup diutamkaan daripada fungsi urban/rural.

- Angka kemiskinan lebih diutamakan daripada kepadatan penduduk.

- Kepadatan penduduk diutamakan daripada fungsi urban/rural.

- Angka kemiskinan lebih diutamakan daripada fungsi urban/rural.

Sedangkan penilaian perbandingan berpasangan untuk elemen Exposure yaitu:

- Data sekunder cukup diutamakan daripada IRS.

- Data sekunder diutamakan daripada persepsi OPD.

- IRS cukup diutamakan daripada persepsi OPD.

Hasil penentuan pembobotan untuk parameter Impact dapat dilihat pada Tabel 2 dan pembobotan untuk parameter Exposure dapat dilihat pada Tabel 3.

Tabel 2. Bobot Parameter Impact

\begin{tabular}{lc}
\hline \multicolumn{1}{c}{ Parameter Impact } & Bobot \\
\hline Jumlah penduduk & $16 \%$ \\
Kepadatan penduduk & $23 \%$ \\
Angka kemiskinan & $52 \%$ \\
Fungsi urban/rural & $9 \%$ \\
\hline
\end{tabular}

Tabel 3. Bobot Parameter Exposure

\begin{tabular}{lc}
\hline Parameter Exposure & Bobot \\
\hline Data sekunder & $54 \%$ \\
IRS & $30 \%$ \\
Persepsi OPD & $16 \%$ \\
\hline
\end{tabular}

\subsection{Penentuan Skor Impact}

Kondisi sanitasi yang buruk lebih merugikan masyarakat dengan kepadatan penduduk yang tinggi karena penyebaran penyakit dapat lebih mungkin terjadi. Daerah dengan risiko persampahan yang tinggi cenderung dapat menyebarkan penyakit di daerah yang memiliki kepadatan penduduk yang tinggi[14]. Hasil perhitungan persentase jumlah penduduk, kepadatan penduduk, angka kemiskinan, dan klasifikasi wilayah $[9,10,11,13]$ yang dikonversi dengan cara normalisasi ke dalam skor 1 hingga 4 ditampilkan pada Tabel 4. Setelah dilakukan normalisasi, setiap parameter Impact dikalikan dengan persentase bobot yang telah dihitung menggunakan Metode AHP, kemudian dijumlahkan per kelurahan, dan hasilnya disebut sebagai skor Impact. Skor Impact yang dikonversi dengan cara normalisasi ke dalam skor 1 hingga 4 ditampilkan pada Tabel 5. 
Tabel 4. Normalisasi Skor Parameter Impact

\begin{tabular}{|c|c|c|c|c|c|c|c|c|c|c|}
\hline \multirow[t]{2}{*}{ No. } & \multirow[t]{2}{*}{ Kelurahan } & \multicolumn{3}{|c|}{ Jumlah Penduduk } & \multicolumn{2}{|c|}{$\begin{array}{l}\text { Kepadatan } \\
\text { Penduduk }\end{array}$} & \multicolumn{2}{|c|}{$\begin{array}{c}\text { Angka } \\
\text { Kemiskinan }\end{array}$} & \multicolumn{2}{|c|}{$\begin{array}{l}\text { Klasifikasi } \\
\text { Wilayah }\end{array}$} \\
\hline & & (jiwa) & $\%$ & $\mathbf{N}$ & (jiwa/ha) & $\mathbf{N}$ & $\%$ & $\mathbf{N}$ & Nilai & $\mathbf{N}$ \\
\hline 1 & Melong & 72.120 & $12,3 \%$ & 4 & 432 & 4 & $4,1 \%$ & 1 & 2 & 1 \\
\hline 2 & Cibeureum & 69.116 & $11,8 \%$ & 4 & 472 & 4 & $9,3 \%$ & 4 & 2 & 1 \\
\hline 3 & Utama & 38.863 & $6,6 \%$ & 2 & 192 & 1 & $7,0 \%$ & 2 & 2 & 1 \\
\hline 4 & Leuwigajah & 48.195 & $8,2 \%$ & 3 & 230 & 2 & $6,2 \%$ & 2 & 2 & 1 \\
\hline 5 & Cibeber & 29.355 & $5,0 \%$ & 2 & 165 & 1 & $5,7 \%$ & 2 & 2 & 1 \\
\hline 6 & Baros & 23.840 & $4,1 \%$ & 1 & 199 & 1 & $5,0 \%$ & 1 & 2 & 1 \\
\hline 7 & Cigugur Tengah & 52.439 & $9,0 \%$ & 3 & 418 & 4 & $9,3 \%$ & 4 & 2 & 1 \\
\hline 8 & Karangmekar & 18.195 & $3,1 \%$ & 1 & 260 & 2 & $6,9 \%$ & 2 & 2 & 1 \\
\hline 9 & Setiamanah & 24.763 & $4,2 \%$ & 1 & 337 & 3 & $7,6 \%$ & 3 & 2 & 1 \\
\hline 10 & Padasuka & 42.481 & $7,3 \%$ & 3 & 402 & 4 & $7,0 \%$ & 2 & 2 & 1 \\
\hline 11 & Cimahi & 12.048 & $2,1 \%$ & 1 & 268 & 2 & $10,4 \%$ & 4 & 2 & 1 \\
\hline 12 & Pasirkaliki & 17.786 & $3,0 \%$ & 1 & 262 & 2 & $5,0 \%$ & 1 & 2 & 1 \\
\hline 13 & Cibabat & 56.407 & $9,6 \%$ & 3 & 368 & 3 & $4,8 \%$ & 1 & 2 & 1 \\
\hline 14 & Citeureup & 39.046 & $6,7 \%$ & 2 & 226 & 2 & $4,7 \%$ & 1 & 2 & 1 \\
\hline 15 & Cipageran & 40.966 & $7,0 \%$ & 2 & 129 & 1 & $5,2 \%$ & 1 & 2 & 1 \\
\hline \multicolumn{2}{|c|}{ Nilai Minimum } & & $2,1 \%$ & & 129 & & $4,1 \%$ & & 2 & \\
\hline \multicolumn{2}{|c|}{ Nilai Maksimum } & & $12,3 \%$ & & 472 & & $10,4 \%$ & & 2 & \\
\hline \multicolumn{2}{|c|}{ Interval Nilai } & & $10,3 \%$ & & 342 & & $6,3 \%$ & & $\mathbf{0}$ & \\
\hline
\end{tabular}

Tabel 5. Penentuan Skor Impact

\begin{tabular}{llcccccc}
\hline No. & Kelurahan & $\begin{array}{c}\text { Jumlah } \\
\text { Penduduk }\end{array}$ & $\begin{array}{c}\text { Kepadatan } \\
\text { Penduduk }\end{array}$ & $\begin{array}{c}\text { Angka } \\
\text { Kemiskinan }\end{array}$ & $\begin{array}{c}\text { Klasifikasi } \\
\text { Wilayah }\end{array}$ & Impact & $\begin{array}{c}\text { Skor } \\
\text { Impact }\end{array}$ \\
\cline { 2 - 6 } & $\mathbf{1 6 \%}$ & $\mathbf{2 3 \%}$ & $\mathbf{5 2 \%}$ & $\mathbf{9 \%}$ & & \\
\hline 1 & Melong & 4 & 4 & 1 & 1 & 2,2 & 2 \\
2 & Cibeureum & 4 & 4 & 4 & 1 & 3,7 & 4 \\
3 & Utama & 2 & 1 & 2 & 1 & 1,7 & 1 \\
4 & Leuwigajah & 3 & 2 & 2 & 1 & 2,1 & 2 \\
5 & Cibeber & 2 & 1 & 2 & 1 & 1,7 & 1 \\
6 & Baros & 1 & 1 & 1 & 1 & 1,0 & 1 \\
7 & Cigugur Tengah & 3 & 4 & 4 & 1 & 3,6 & 4 \\
8 & Karangmekar & 1 & 2 & 2 & 1 & 1,8 & 2 \\
9 & Setiamanah & 1 & 3 & 3 & 1 & 2,5 & 3 \\
10 & Padasuka & 3 & 4 & 2 & 1 & 2,5 & 3 \\
11 & Cimahi & 1 & 2 & 4 & 1 & 2,8 & 3 \\
12 & Pasirkaliki & 1 & 2 & 1 & 1 & 1,2 & 1 \\
13 & Cibabat & 3 & 3 & 1 & 1 & 1,8 & 2 \\
14 & Citeureup & 2 & 2 & 1 & 1 & 1,4 & 1 \\
15 & Cipageran & 2 & 1 & 1 & 1 & 1,2 & 1 \\
\hline Skor Minimum & & & & & $\mathbf{1 , 0}$ & \\
Skor Maksimum & & & & & $\mathbf{3 , 7}$ & \\
Interval Skor & & & & & & \\
\hline
\end{tabular}




\subsection{Penentuan Skor Exposure}

Hasil perhitungan persentase reduksi sampah setiap kelurahan yang dikonversi dengan cara normalisasi ke dalam skor 1 hingga 4 ditampilkan pada Tabel 6 [12]. Semakin rendah persentase reduksi sampah, maka semakin tinggi skor risiko persampahannya sehingga terdapat pengecualian pada normalisasi skor data sekunder. Normalisasi untuk skor data sekunder mengikuti Persamaan 15 s.d. 18.

$X>\left[X_{\min }+75 \% \cdot\left(X_{\max }-X_{\text {min }}\right)\right] \rightarrow$ Skor 1
$X>\left[X_{\min }+50 \% \cdot\left(X_{\max }-X_{\text {min }}\right)\right] \rightarrow$ Skor 2
$X>\left[X_{\min }+25 \% \cdot\left(X_{\max }-X_{\text {min }}\right)\right] \rightarrow$ Skor 3
$X>\left[X_{\text {min }}+0 \% \cdot\left(X_{\text {max }}-X_{\text {min }}\right)\right] \rightarrow$ Skor 4.

Tabel 6. Penentuan Skor Data Sekunder

\begin{tabular}{|c|c|c|c|c|c|}
\hline No. & Kelurahan & $\begin{array}{c}\text { Jumlah } \\
\text { Timbulan } \\
\text { Sampah } \\
\text { (ton/hari) }\end{array}$ & $\begin{array}{c}\text { Jumlah } \\
\text { Sampah } \\
\text { Tereduksi } \\
\text { (ton/hari) }\end{array}$ & $\begin{array}{l}\text { Reduksi } \\
\text { Sampah }\end{array}$ & $\begin{array}{l}\text { Skor Data } \\
\text { Sekunder }\end{array}$ \\
\hline 1 & Melong & 33,09 & 2,31 & $7 \%$ & 4 \\
\hline 2 & Cibeureum & 31,71 & 0,66 & $2 \%$ & 4 \\
\hline 3 & Utama & 17,83 & 2,33 & $13 \%$ & 3 \\
\hline 4 & Leuwigajah & 22,11 & 4,55 & $21 \%$ & 3 \\
\hline 5 & Cibeber & 13,47 & 0,62 & $5 \%$ & 4 \\
\hline 6 & Baros & 10,94 & 1,86 & $17 \%$ & 3 \\
\hline 7 & Cigugur Tengah & 24,06 & 2,95 & $12 \%$ & 3 \\
\hline 8 & Karangmekar & 8,35 & 1,77 & $21 \%$ & 2 \\
\hline 9 & Setiamanah & 11,36 & 0,07 & $1 \%$ & 4 \\
\hline 10 & Padasuka & 19,49 & 1,69 & $9 \%$ & 4 \\
\hline 11 & Cimahi & 5,53 & 2,29 & $41 \%$ & 1 \\
\hline 12 & Pasirkaliki & 8,16 & 0,02 & $0,3 \%$ & 4 \\
\hline 13 & Cibabat & 25,88 & 5,31 & $21 \%$ & 3 \\
\hline 14 & Citeureup & 17,92 & 0,75 & $4 \%$ & 4 \\
\hline 15 & Cipageran & 18,80 & 2,27 & $12 \%$ & 3 \\
\hline \multicolumn{2}{|c|}{ Jumlah } & 268,70 & 29,44 & & \\
\hline \multicolumn{2}{|c|}{ Nilai Minimum } & & & $0 \%$ & \\
\hline \multicolumn{2}{|c|}{ Nilai Maksimum } & & & $41 \%$ & \\
\hline \multicolumn{2}{|c|}{ Interval Nilai } & & & $41 \%$ & \\
\hline
\end{tabular}

Nilai indeks risiko persampahan (IRS) ditentukan sesuai dengan strata kelurahan tersebut. Strata 2 memiliki nilai IRS 17, strata 3 memiliki nilai IRS 15, dan strata 4 memiliki nilai IRS 9. Hasil penentuan skor IRS setiap kelurahan yang dikonversi dengan cara normalisasi ke dalam skor 1 hingga 4 ditampilkan pada Tabel 7. Salah satu unsur perangkat daerah kabupaten/kota adalah dinas daerah [17]. Nilai persepsi Organisasi Perangkat Daerah (OPD) diperoleh melalui hasil wawancara kepala dan staf seksi bidang persampahan di Dinas Lingkungan Hidup Kota Cimahi [12]. Skor yang paling sering muncul dipilih sebagai skor akhir OPD. Hasil penentuan skor OPD setiap kelurahan ini ditampilkan pada Tabel 8 . 
Tabel 7. Penentuan Skor Indeks Risiko Persampahan (IRS)

\begin{tabular}{clccc}
\hline No. & \multicolumn{1}{c}{ Kelurahan } & Strata & IRS & $\begin{array}{c}\text { Skor } \\
\text { IRS }\end{array}$ \\
\hline 1 & Melong & 3 & 15 & 3 \\
2 & Cibeureum & 4 & 9 & 1 \\
3 & Utama & 4 & 9 & 1 \\
4 & Leuwigajah & 2 & 17 & 4 \\
5 & Cibeber & 2 & 17 & 4 \\
6 & Baros & 2 & 17 & 4 \\
7 & Cigugur Tengah & 4 & 9 & 1 \\
8 & Karangmekar & 3 & 15 & 3 \\
9 & Setiamanah & 3 & 15 & 3 \\
10 & Padasuka & 3 & 15 & 3 \\
11 & Cimahi & 3 & 15 & 3 \\
12 & Pasirkaliki & 2 & 17 & 4 \\
13 & Cibabat & 3 & 15 & 3 \\
14 & Citeureup & 2 & 17 & 4 \\
15 & Cipageran & 2 & 17 & 4 \\
\hline Nilai Minimum & & $\mathbf{9}$ & \\
Nilai Maksimum & & $\mathbf{1 7}$ & \\
Interval Nilai & & $\mathbf{8}$ & \\
\hline
\end{tabular}

Tabel 8. Penentuan Skor Organisasi Perangkat Daerah (OPD)

\begin{tabular}{|c|c|c|c|c|c|c|c|c|}
\hline \multirow[t]{2}{*}{ No. } & \multirow[t]{2}{*}{ Kelurahan } & \multicolumn{6}{|c|}{ Nilai Persepsi OPD } & \multirow{2}{*}{$\begin{array}{l}\text { Skor } \\
\text { OPD }\end{array}$} \\
\hline & & I & II & III & IV & $\mathbf{V}$ & VI & \\
\hline 1 & Melong & 3 & 3 & 4 & 3 & 4 & 3 & 3 \\
\hline 2 & Cibeureum & 3 & 4 & 2 & 3 & 4 & 3 & 3 \\
\hline 3 & Utama & 3 & 3 & 2 & 3 & 4 & 3 & 3 \\
\hline 4 & Leuwigajah & 3 & 3 & 3 & 3 & 4 & 3 & 3 \\
\hline 5 & Cibeber & 2 & 3 & 1 & 3 & 4 & 3 & 3 \\
\hline 6 & Baros & 2 & 2 & 2 & 2 & 4 & 2 & 2 \\
\hline 7 & Cigugur Tengah & 1 & 2 & 2 & 3 & 4 & 2 & 2 \\
\hline 8 & Karangmekar & 2 & 3 & 2 & 2 & 4 & 2 & 2 \\
\hline 9 & Setiamanah & 2 & 3 & 2 & 2 & 4 & 2 & 2 \\
\hline 10 & Padasuka & 2 & 2 & 2 & 2 & 4 & 2 & 2 \\
\hline 11 & Cimahi & 2 & 2 & 2 & 2 & 4 & 2 & 2 \\
\hline 12 & Pasirkaliki & 1 & 1 & 1 & 1 & 4 & 2 & 1 \\
\hline 13 & Cibabat & 2 & 2 & 2 & 1 & 4 & 2 & 2 \\
\hline 14 & Citeureup & 2 & 2 & 1 & 2 & 4 & 2 & 2 \\
\hline 15 & Cipageran & 2 & 2 & 2 & 2 & 4 & 2 & 2 \\
\hline
\end{tabular}

Keterangan Tabel 8:

I = Kepala Seksi Manajemen Pengelolaan Persampahan dan Limbah B3

II = Staf Seksi Manajemen Pengelolaan Persampahan dan Limbah B3

III = Staf Seksi Sarana Prasarana Persampahan

IV = Kepala Seksi Sarana Prasarana Persampahan

$\mathrm{V} \quad=$ Kepala Seksi Peningkatan Kapasitas Lingkungan Hidup

VI = Kepala Unit Pelaksana Teknis Dinas Pelayanan Persampahan 
Setelah dilakukan perhitungan dan normalisasi, setiap parameter Exposure dikalikan dengan persentase bobot yang telah dihitung menggunakan Metode AHP, kemudian dijumlahkan per kelurahan, dan hasilnya disebut sebagai skor Exposure. Skor Exposure yang dikonversi dengan cara normalisasi ke dalam skor 1 hingga 4 ditampilkan pada Tabel 9.

Tabel 9. Penentuan Skor Exposure

\begin{tabular}{llccccc}
\hline No. & \multicolumn{1}{c}{ Kelurahan } & $\begin{array}{c}\text { Data } \\
\text { Sekunder }\end{array}$ & IRS & OPD & Exposure & $\begin{array}{c}\text { Skor } \\
\text { Exposure }\end{array}$ \\
\cline { 2 - 4 } & $\mathbf{5 4 \%}$ & $\mathbf{3 0 \%}$ & $\mathbf{1 6 \%}$ & & \\
\hline 1 & Melong & 4 & 3 & 3 & 3,5 & 4 \\
2 & Cibeureum & 4 & 1 & 3 & 2,9 & 3 \\
3 & Utama & 3 & 1 & 3 & 2,4 & 2 \\
4 & Leuwigajah & 3 & 4 & 3 & 3,3 & 3 \\
5 & Cibeber & 4 & 4 & 3 & 3,8 & 4 \\
6 & Baros & 3 & 4 & 2 & 3,1 & 3 \\
7 & Cigugur Tengah & 3 & 1 & 2 & 2,2 & 1 \\
8 & Karangmekar & 2 & 3 & 2 & 2,3 & 2 \\
9 & Setiamanah & 4 & 3 & 2 & 3,4 & 4 \\
10 & Padasuka & 4 & 3 & 2 & 3,4 & 4 \\
11 & Cimahi & 1 & 3 & 2 & 1,8 & 1 \\
12 & Pasirkaliki & 4 & 4 & 1 & 3,5 & 4 \\
13 & Cibabat & 4 & 3 & 2 & 3,4 & 4 \\
14 & Citeureup & 3 & 4 & 2 & 3,1 & 3 \\
15 & Cipageran & 3 & 4 & 2 & 3,1 & 3 \\
\hline Skor Minimum & & & & $\mathbf{1 , 8}$ & \\
Skor Maksimum & & & & $\mathbf{3 , 8}$ & \\
Interval Skor & & & & $\mathbf{2 , 1}$ & \\
\hline
\end{tabular}

\subsection{Penggambaran Skor Area Berisiko Persampahan}

Area berisiko persampahan dihitung melalui hasil perkalian antara parameter Impact dan parameter Exposure. Hasil perhitungan dan normalisasi skor area berisiko untuk setiap kelurahan di Kota Cimahi ditampilkan pada Tabel 10. Sedangkan Gambar 2 menunjukkan hasil penentuan area berisiko untuk setiap kelurahan di Kota Cimahi.

\subsection{Strategi Pengurangan Persampahan berdasarkan Area Berisiko Persampahan}

Strategi yang direncanakan pada penelitian ini berfokus pada aspek teknis pengurangan sampah di Kota Cimahi. Skenario yang terdapat dalam strategi di bawah ini adalah merencanakan penambahan unit-unit pengolahan sampah, berupa composting plant, reaktor kompos, dan TPS 3R. Kapasitas unit pengolahan composting plant, reaktor kompos, dan TPS $3 \mathrm{R}$ secara berturut-turut adalah 0,$615 ; 0,034$; dan 1,601 dalam satuan ton/unit/hari. Ketiga unit pengolahan tersebut memiliki kapasitas pengolahan yang lebih besar jika dibandingkan dengan kapasitas unit pengolahan sampah lainnya yang telah diterapkan di Kota Cimahi, seperti unit komposter ( 0,01 ton/unit/hari), biodigester ( 0,021 ton/unit/hari), dan bank sampah (0,022 ton/unit/hari). Dengan demikian, penambahan ketiga unit pengolahan tersebut diutamakan. 
Tabel 10. Penentuan Skor Area Berisiko

\begin{tabular}{clcccc}
\hline No. & \multicolumn{1}{c}{ Kelurahan } & Impact & Exposure & $\begin{array}{c}\text { Skor } \\
\text { Risiko }\end{array}$ & $\begin{array}{c}\text { Skor } \\
\text { Risiko } \\
\text { (Normal) }\end{array}$ \\
& & & & & \\
\hline 1 & Melong & 2 & 4 & 8 & 3 \\
2 & Cibeureum & 4 & 3 & 12 & 4 \\
3 & Utama & 1 & 2 & 2 & 1 \\
4 & Leuwigajah & 2 & 3 & 6 & 2 \\
5 & Cibeber & 1 & 4 & 4 & 1 \\
6 & Baros & 1 & 3 & 3 & 1 \\
7 & Cigugur Tengah & 4 & 1 & 4 & 1 \\
8 & Karangmekar & 2 & 2 & 4 & 1 \\
9 & Setiamanah & 3 & 4 & 12 & 4 \\
10 & Padasuka & 3 & 4 & 12 & 4 \\
11 & Cimahi & 3 & 1 & 3 & 1 \\
12 & Pasirkaliki & 1 & 4 & 4 & 1 \\
13 & Cibabat & 2 & 3 & 6 & 2 \\
14 & Citeureup & 1 & 3 & 3 & 1 \\
15 & Cipageran & 1 & 3 & 3 & 1 \\
\hline Skor Minimum & & & 2 & \\
Skor Maksimum & & & 12 & \\
Interval Skor & & & 10 & \\
\hline
\end{tabular}

Penambahan unit reaktor kompos direncanakan karena terdapat TPST di beberapa kelurahan di Kota Cimahi yang berpotensi sebagai tempat penyimpanan dan pengoperasian reaktor kompos. Dengan adanya tambahan reaktor kompos, diharapkan terjadi peningkatan reduksi sampah di TPST dan pengoptimalan operasional TPST di kelurahan tersebut. Reaktor kompos dapat digunakan jika terdapat cukup lahan dan terdapat tenaga operasional.

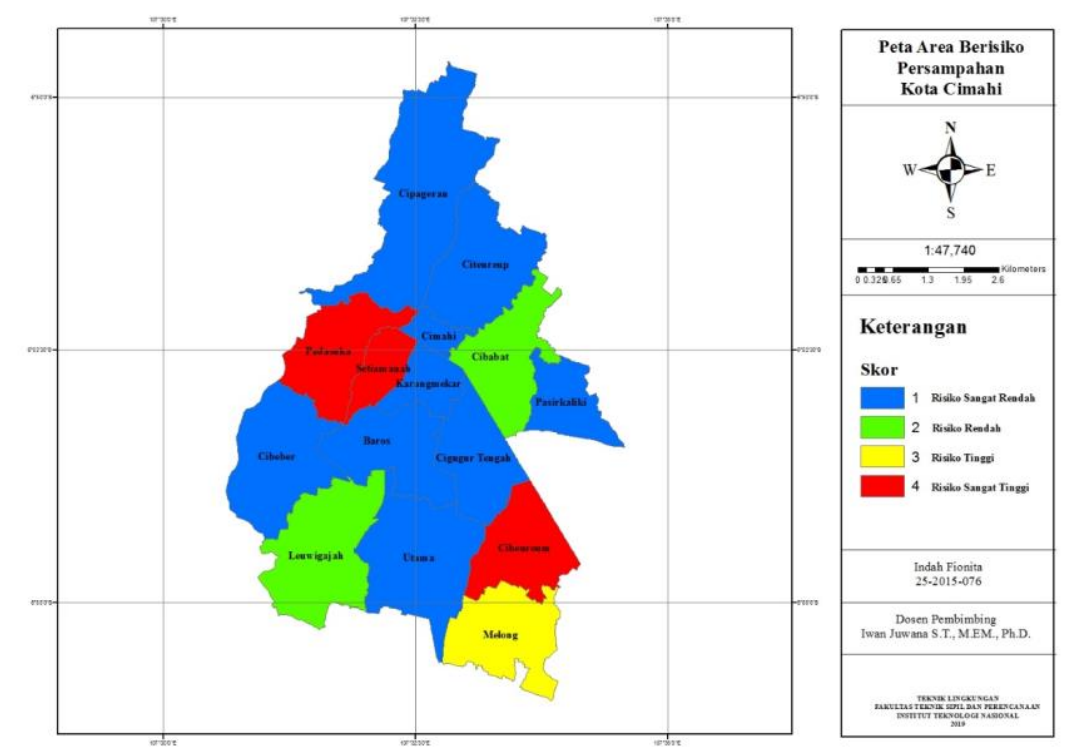

Gambar 2. Peta Area Berisiko Persampahan Kota Cimahi 
Penambahan unit reaktor kompos direncanakan karena terdapat TPST di beberapa kelurahan di Kota Cimahi yang berpotensi sebagai tempat penyimpanan dan pengoperasian reaktor kompos. Dengan adanya tambahan reaktor kompos, diharapkan terjadi peningkatan reduksi sampah di TPST dan pengoptimalan operasional TPST di kelurahan tersebut. Reaktor kompos dapat digunakan jika terdapat cukup lahan dan terdapat tenaga operasional.

Penambahan unit composting plant direncanakan karena mampu mereduksi sampah yang cukup besar yaitu 0,601 ton/hari. Composting plant dapat diterapkan menggunakan metode open windrow atau bioreaktor mini. Metode open windrow dapat dilaksanakan jika tersedia lahan yang luas sehingga mampu menempatkan materi pengomposan dengan lebar 1,8 - 3,5 meter, tinggi 1,2 - 2,5 meter, dan panjang yang disesuaikan serta terdapat pekerja untuk kegiatan operasional [15]. Bioreaktor mini dapat dioperasikan di lahan yang sempit serta diperlukan partisipasi dari masyarakat.

Penambahan unit TPS 3R direncanakan karena kapasitas pengolahan TPS 3R, yang besarnya adalah 1,601 ton/unit/hari, berpotensi paling besar dalam meningkatkan persentase reduksi sampah dibandingkan jenis pengolahan lain yang terdapat di kelurahan tersebut. Penambahan unit TPS 3R dapat dilakukan dengan mengalihfungsikan beberapa TPS yang sudah ada menjadi TPS 3R apabila terdapat pemilahan sampah di wilayah pelayanan, terdapat pekerja operasional, dan terdapat luas lahan TPS yang lebih besar dari $200 \mathrm{~m}^{2}$ ataupun dilakukan melalui pembangunan unit TPS 3R sesuai dengan PermenPU No. 3 Tahun 2013 [16].

Unit-unit pengolahan lainnya di Kota Cimahi, seperti komposter, biodigester, dan bank sampah merupakan bagian dari program pengelolaan sampah berbasis masyarakat. Pada tahun 2019, Pemerintah Kota Cimahi telah menyediakan 48 unit komposter, 3 unit biodigester, dan 58 unit bank sampah. Hal yang menjadi fokus pada ketiga jenis pengolahan sampah tersebut bukanlah pada penambahan unit, namun pada penerapan di masyarakat. Melalui program yang telah diadakan oleh Pemkot Cimahi, diharapkan terjadi peran serta aktif masyarakat, optimalisasi pemanfaatan unit-unit tersebut dan, adanya reduksi sampah sejak dari sumber [2].

Tabel 11. Strategi Pengurangan Sampah di Kota Cimahi

\begin{tabular}{|c|c|c|c|c|c|}
\hline \multirow[t]{2}{*}{ No. } & \multirow[t]{2}{*}{ Kelurahan } & \multicolumn{2}{|c|}{ Jenis Pengolahan } & \multicolumn{2}{|c|}{ Reduksi Sampah } \\
\hline & & $\begin{array}{c}\text { Kondisi } \\
\text { Eksisting }\end{array}$ & Strategi & $\begin{array}{l}\text { Kondisi } \\
\text { Eksisting }\end{array}$ & Strategi \\
\hline 1 & Melong & $1 \mathrm{TPS} 3 \mathrm{R}$ & 2 TPS 3R & $7 \%$ & $12 \%$ \\
\hline 2 & Cibeureum & Tidak ada TPS 3R & 4 TPS 3R & $2 \%$ & $22 \%$ \\
\hline 3 & Cibeber & Tidak ada TPS 3R & 1 TPS 3R & $5 \%$ & $16 \%$ \\
\hline 4 & Setiamanah & $\begin{array}{l}\text { Tidak ada } \\
\text { composting plant; } \\
\text { Tidak ada TPS 3R }\end{array}$ & $\begin{array}{l}2 \text { composting } \\
\text { plant; } \\
1 \text { TPS 3R }\end{array}$ & $1 \%$ & $26 \%$ \\
\hline 5 & Padasuka & $\begin{array}{l}1 \text { composting } \\
\text { plant; } \\
\text { Tidak ada TPS 3R }\end{array}$ & $\begin{array}{l}2 \text { composting } \\
\text { plant; } \\
2 \text { TPS 3R }\end{array}$ & $9 \%$ & $28 \%$ \\
\hline 6 & Pasirkaliki & Tidak ada TPS 3R & $1 \mathrm{TPS} 3 \mathrm{R}$ & $0,3 \%$ & $20 \%$ \\
\hline 7 & Citeureup & Tidak ada TPS 3R & $1 \mathrm{TPS} 3 \mathrm{R}$ & $4 \%$ & $13 \%$ \\
\hline
\end{tabular}

Tabel 11 menunjukkan strategi pengurangan sampah di Kota Cimahi. Dengan adanya penambahan dan/atau pengaktifan kembali fasilitas pengolahan sampah di Kota Cimahi, maka dapat terjadi perubahan skor Exposure yang selanjutnya berpengaruh juga terhadap perubahan skor Area Berisiko Persampahan. Hasil perhitungan skor Exposure setelah adanya strategi pengurangan sampah dapat 
dilihat pada Tabel 12. Hasil perhitungan skor Area Berisiko Persampahan setelah adanya strategi pengurangan sampah dapat dilihat pada Tabel 13.

Tabel 12. Skor Exposure dengan Strategi Pengurangan Sampah

\begin{tabular}{llccccc}
\hline No & Kelurahan & $\begin{array}{c}\text { Data } \\
\text { Sekunder }\end{array}$ & IRS & $\begin{array}{c}\text { Persepsi } \\
\text { OPD }\end{array}$ & Exposure & $\begin{array}{c}\text { Skor } \\
\text { Exposure }\end{array}$ \\
\cline { 2 - 4 } & $\mathbf{5 4 \%}$ & $\mathbf{3 0 \%}$ & $\mathbf{1 6 \%}$ & & \\
\hline 1 & Melong & 3 & 3 & 3 & 3,0 & 3 \\
2 & Cibeureum & 2 & 1 & 3 & 1,9 & 1 \\
3 & Utama & 3 & 1 & 3 & 2,4 & 2 \\
4 & Leuwigajah & 3 & 4 & 3 & 3,3 & 3 \\
5 & Cibeber & 3 & 4 & 3 & 3,3 & 3 \\
6 & Baros & 3 & 4 & 2 & 3,1 & 3 \\
7 & Cigugur Tengah & 3 & 1 & 2 & 2,2 & 1 \\
8 & Karangmekar & 3 & 3 & 2 & 2,8 & 3 \\
9 & Setiamanah & 2 & 3 & 2 & 2,3 & 2 \\
10 & Padasuka & 2 & 3 & 2 & 2,3 & 2 \\
11 & Cimahi & 1 & 3 & 2 & 1,8 & 1 \\
12 & Pasirkaliki & 3 & 4 & 1 & 3,0 & 3 \\
13 & Cibabat & 3 & 3 & 2 & 2,8 & 3 \\
14 & Citeureup & 3 & 4 & 2 & 3,1 & 3 \\
15 & Cipageran & 3 & 4 & 2 & 3,1 & 3 \\
\hline Skor Minimum & & & & 1,8 & \\
Skor Maksimum & & & & 3,8 & \\
Interval Skor & & & & 2,1 & \\
\hline
\end{tabular}

Tabel 13. Skor Area Berisiko dengan Strategi Pengurangan Sampah

\begin{tabular}{llcccc}
\hline No & \multicolumn{1}{c}{ Kelurahan } & Impact & Exposure & $\begin{array}{c}\text { Skor } \\
\text { Risiko }\end{array}$ & $\begin{array}{c}\text { Skor } \\
\text { Risiko } \\
\text { (Normal) }\end{array}$ \\
\hline 1 & Melong & 2 & 3 & 6 & 2 \\
2 & Cibeureum & 4 & 1 & 4 & 1 \\
3 & Utama & 1 & 2 & 2 & 1 \\
4 & Leuwigajah & 2 & 3 & 6 & 2 \\
5 & Cibeber & 1 & 3 & 3 & 1 \\
6 & Baros & 1 & 3 & 3 & 1 \\
7 & Cigugur Tengah & 4 & 1 & 4 & 1 \\
8 & Karangmekar & 2 & 3 & 6 & 2 \\
9 & Setiamanah & 3 & 2 & 6 & 2 \\
10 & Padasuka & 3 & 2 & 6 & 2 \\
11 & Cimahi & 3 & 1 & 3 & 1 \\
12 & Pasirkaliki & 1 & 3 & 3 & 1 \\
13 & Cibabat & 2 & 3 & 6 & 2 \\
14 & Citeureup & 1 & 3 & 3 & 1 \\
15 & Cipageran & 1 & 3 & 3 & 1 \\
\hline Skor Minimum & & & 2 & \\
Skor Maksimum & & & 12 & \\
Interval Skor & & & 10 & \\
\hline
\end{tabular}


Gambar 3 menunjukkan perubahan area berisiko persampahan sebelum dan sesudah adanya strategi pengurangan sampah di Kota Cimahi.

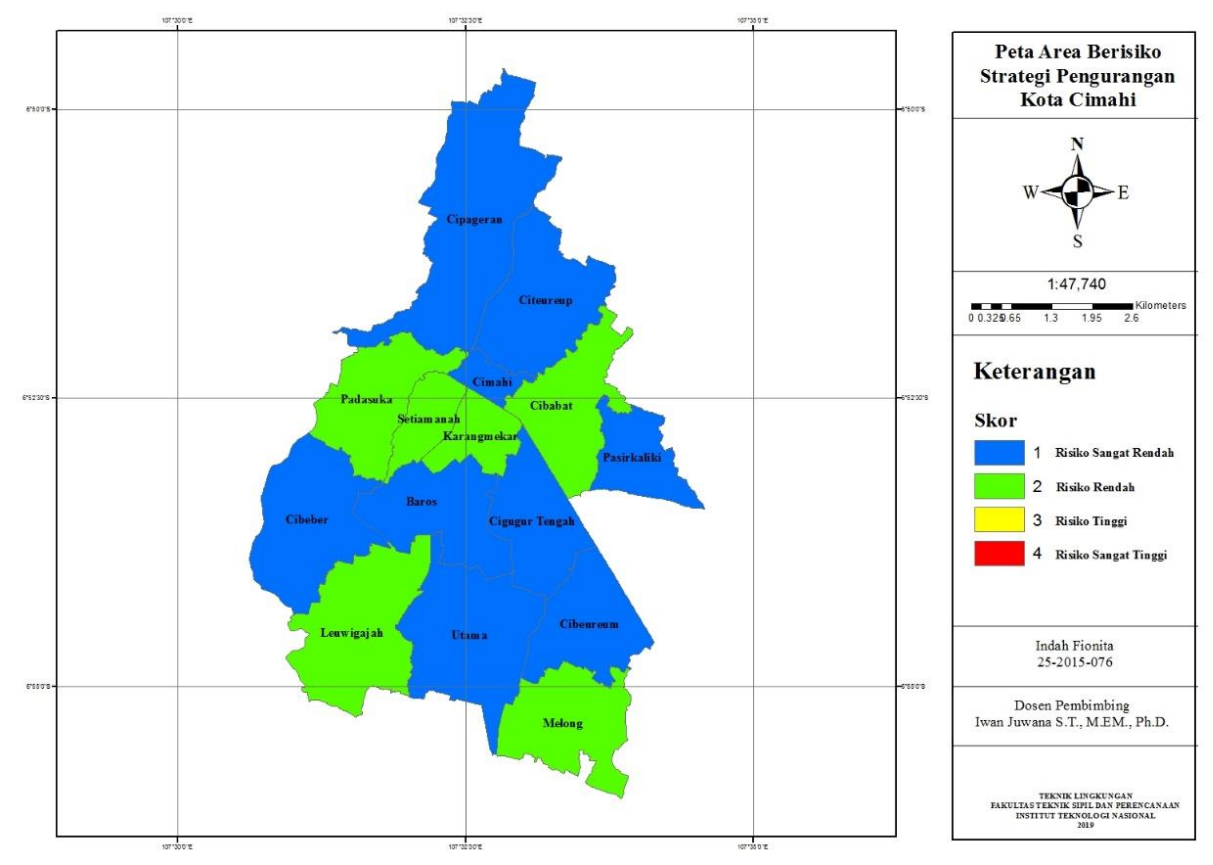

\section{Gambar 3. Peta Area Berisiko Persampahan Kota Cimahi dengan Adanya Strategi Pengurangan Sampah}

\section{KESIMPULAN}

Berdasarkan hasil penentuan area berisiko yang telah dilakukan, terdapat 3 kelurahan yang terindikasi memiliki risiko persampahan sangat tinggi, 1 kelurahan yang terindikasi memiliki risiko persampahan tinggi, 2 kelurahan yang terindikasi memiliki risiko persampahan rendah, dan 9 kelurahan yang terindikasi memiliki risiko persampahan sangat rendah. Kelurahan yang perlu dijadikan prioritas dalam pemberian strategi pengelolaan persampahan adalah kelurahan yang berisiko sangat tinggi yaitu Kelurahan Cibeureum, Kelurahan Setiamanah, dan Kelurahan Padasuka serta kelurahan yang berisiko tinggi yaitu Kelurahan Melong. Strategi yang direkomendasikan melalui penambahan dan/atau pengaktifan kembali fasilitas pengolahan sampah berupa TPS 3R dan/atau composting plant di beberapa kelurahan di Kota Cimahi, yakni Kelurahan Melong, Kelurahan Cibeureum, Kelurahan Cibeber, Kelurahan Setiamanah, Keluraha Padasuka, Kelurahan Pasirkaliki, dan Kelurahan Citeureup.

\section{DAFTAR PUSTAKA}

[1] Adi Haryanto, "Aliran Sungai di Cimahi Dipenuhi Sampah", https://jabar.sindonews. com/read/2856/1/aliran-sungai-di-cimahi-dipenuhi-sampah-ini-penampakannya 1542784291 (diakses pada Mei 2019), 2018.

[2] Kementerian Lingkungan Hidup dan Kehutanan, Buku II Laporan Utama Dokumen Informasi Kinerja Lingkungan Hidup Daerah Kota Cimahi Tahun 2019. 
[3] Peraturan Presiden Republik Indonesia Nomor 97 Tahun 2017 tentang Kebijakan dan Strategi Nasional Pengelolaan Sampah Rumah Tangga dan Sampah Sejenis Sampah Rumah Tangga.

[4] Syaifullah, Pengenalan Metode AHP (Analytical Hierarchy Process), 2010.

[5] Kusnuri, Konsep dan Aplikasi Sistem Pendukung Keputusan, Yogyakarta: Andi, 2007.

[6] Kementerian Pekerjaan Umum dan Perumahan Rakyat Republik Indonesia, Pedoman Penyusunan Strategi Sanitasi Kabupaten/Kota Tahun 2018.

[7] Kementerian Kesehatan Republik Indonesia, Panduan Praktis Pelaksanaan EHRA (Environmental Health Risk Assessment/Penilaian Risiko Kesehatan Lingkungan), 2014.

[8] Jumadil Azhar, Penilaian Risiko Kesehatan Lingkungan di Dusun Kokoa Desa Marannu Kecamatan Lau Kabupaten Maros Tahun 2015, Makassar: UIN Alauddin.

[9] Badan Pusat Statisika Kota Cimahi, Kecamatan Cimahi Selatan Dalam Angka 2018.

[10] Badan Pusat Statisika Kota Cimahi, Kecamatan Cimahi Tengah Dalam Angka 2018.

[11] Badan Pusat Statisika Kota Cimahi, Kecamatan Cimahi Utara Dalam Angka 2018.

[12] Dinas Lingkungan Hidup Kota Cimahi, 2019.

[13] Dinas Perumahan dan Kawasan Permukiman, 2019.

[14] Diane Coffey, Sabrina Haque, Payal Hathi, Lovey Pant, and Dean Spears, Place and Child Health: The Interaction of Population Density and Sanitation in Developing Countries, 2016.

[15] Carsten Bachert, Werner Bidlingmaier, and Suraphong Wattanachira, Open Windrow Composting Manual, Germany: Bauhaus University Weimar, 2008.

[16] Peraturan Menteri Pekerjaan Umum Republik Indonesia Nomor 3 Tahun 2013 tentang Penyelenggaraan Prasarana dan Sarana Persampahan dalam Penanganan Sampah Rumah Tangga dan Sampah Sejenis Sampah Rumah Tangga.

[17] Peraturan Pemerintah Republik Indonesia Nomor 41 Tahun 2007 tentang Organisasi Perangkat Daerah.

[18] Kementerian Pendidikan dan Budaya, Kamus Besar Bahsa Indonesia (KBBI), https://kbbi.kemdikbud.go.id/entri/dampak (diakses pada Juni 2019), 2016.

[19] Cambridge University Press, Cambridge Dictionary, https://dictionary.cambridge.org/ dictionary/english/exposure (diakses pada Juni 2019), 2019.

[20] Marimin, Teknik dan Aplikasi Pengambilan Kepurusan Kriteria Manjemuk, Jakarta:Grasindo, 2004. 